\title{
Is Human Oxoguanine Glycosylase 1 Genetic Variant Successful Even on Oral Squamous Cell Carcinoma?
}

\author{
Levent Aydemir ${ }^{\mathrm{a}}$ Elif Sinem Bireller ${ }^{\mathrm{b}}$ Hakan Avci $^{\mathrm{a}}$ Zeynep Boy Metin ${ }^{\mathrm{c}}$ \\ Kemal Deger $^{\mathrm{a}}$ Meral Unur $^{\mathrm{c}}$ Bedia Cakmakoglu $^{\mathrm{d}}$

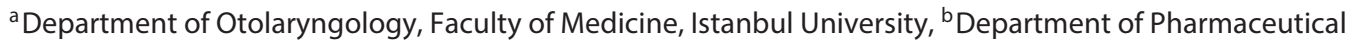 \\ Microbiology, Faculty of Pharmacy, Istanbul Yeni Yuzyil University, ${ }^{C}$ Department of Oral Surgery and Medicine, Dental \\ Faculty, and d Department of Molecular Medicine, Institute of Experimental Medical Research, Istanbul University, \\ Istanbul, Turkey
}

\section{Keywords}

Oral squamous cell carcinoma $\cdot$ Human oxoguanine

glycosylase 1-Ser326Cys · APE-Asp148Glu

\begin{abstract}
Background: Oral squamous cell carcinoma (OSCC) is one of the most widespread cancer types that arise from different sites of oral cavity and has a 5 -year survival rate. This study is aimed at investigating the human oxoguanine glycosylase 1 (hOGG1)-Ser326Cys and APE-Asp148Glu polymorphisms of DNA repair genes in OSCC. Materials and Methods: We investigated the hOGG1-Ser326Cys and APE-Asp148Glu polymorphisms of DNA repair genes in the oral cavity. Genotyping was conducted using polymerase chain reaction-restriction fragment length polymorphism analysis based on 132 patients who were diagnosed as having OSCC and 160 healthy subjects. Results: Individuals with the genotype hOGG1-Ser326Cys, Cys allele carriers, were found significantly more frequently in the patient group compared to the control group as increase in risk $(p<0.001)$. Furthermore, it was observed that there were significantly more individuals with the Ser allele in the control group $(p<0.001)$. Individuals with genotype APE-Asp148Glu were not statistically significant; however, they were still more in the control group
\end{abstract}

\section{KARGER}

(C) 2017 S. Karger AG, Basel

E-Mail karger@karger.com

www.karger.com/pat and provided protection against the disease. Conclusion: Our findings showed that hOGG1-Ser326Cys Cys allele is statistically important and relevant with respect to the development of oral squamous cancer. In view of our results, further studies including expression levels are required in which hOGG1-Ser326Cys should be investigated as molecular biomarkers for the early prediction of squamous cell carcinoma.

(c) 2017 S. Karger AG, Basel

\section{Introduction}

Head and neck cancer accounts for about $5 \%$ of all malignant tumors and is the sixth most common tumor [1]. Tumors in head and neck regions comprise the oral cavity, skin, nasal cavity and paranasal sinuses, nasopharynx, lips, oropharynx, larynx, hypopharynx and cervical esophagus, cervical trachea, neck, salivary glands, and parapharyngeal space. Oral squamous cell carcinoma (OSCC) is most common with $90 \%$ range of the oral cavity disease [2-4].

Many factors have been identified in the cancer development process, such as biological and environmental factors, as well as smoking habits and alcohol exposure $[1,5]$. Smoking and alcohol are related to oral cav-

Prof. Dr. Bedia Cakmakoglu

Department of Molecular Medicine, Institute of Experimental Medical Research Istanbul University, Capa

TR-34000 Istanbul (Turkey)

E-Mail bedia@istanbul.edu.tr 
Table 1. Gene variants and primers

\begin{tabular}{ll}
\hline Gene variants & Primers \\
\hline APE-Asp148Glu & Forward primer: 5'-CTG TTT CAT TTC TAT AGG CTA-3' \\
rs3136820 & Reverse primer: 5'-AGG AAC TTG CGA AAG GCT TC-3' \\
hOGG1-Ser326Cys & Forward primer: 5'-ACT GTC ACT AGT CTC ACC AG-3' \\
rs1052133 & Reverse primer: 5'-GGA AGG TGC TTG GGG AAT-3' \\
\hline
\end{tabular}

ity diseases in the same way; they are significant carcinogens in almost all kinds of cancer mechanisms. OSCC has an incontrovertible relation with smoking and alcohol abuse in about $90 \%$ of cases. Other important etiologic factors have been considered such as viruses, genetic factors, ultraviolet and radiation exposure, oral hygiene, and diet [1]. Radiation exposure, environmental chemicals, and other toxic molecules also play a significant role in the development of cancer processes. These molecules must be metabolized using the body's enzyme system in homeostasis. If any reactive oxygen species (ROS) occur in this process, it might result in the induction of DNA damage. When the DNA repairing system started not to work properly such as by modifications, polymorphisms, unbroken protein process, the system process could end up with damaged DNA and genetic instability. These results most effectively lead to cancer [6]. It is well known that DNA, main or underlying, has a definite role in diseases including cancer [7-10].

The elimination and repair of damaged DNA is facilitated by DNA repair mechanisms, which have 4 major mechanisms [11-14]. The base excision repair (BER) pathway is one of the major mechanisms, which provides systemic protection against ROS $[11,14,15]$. It is possible to hypothesize that BER mechanism and oral mucosa damage directly. The oral mucosa comes into direct contact with some carcinogens such as alcohol and tobacco, which leads to the production of oxidative stress [12, 13]. Human oxoguanine glycosylase 1 (hOGG1) and human apurinic/apyrimidinic endonuclease/redox factor 1 (APE1) are both members of the BER pathway [16-18]. Polymorphisms individual or combined on hOGG1 and APE1 might end up reasonable for disease development including OSCC. In this respect, we aimed to investigate a molecular-based study to find a possible correlation with DNA repair genes and OSCC. We believe that our results provide important information for future expression studies in this area by focusing on DNA repair pathway.

\section{Materials and Methods}

Subject Selection

Blood samples were collected in EDTA-containing tubes from 132 patients diagnosed as having OSCC and 160 healthy subjects, who presented to the Ear, Nose and Throat Clinic and Dental Clinic at Istanbul Medical Faculty between August 2007 and August 2013. All participants, patients, and controls gave written informed consent and the study was approved by the Medical Ethics Committee of Istanbul Medical Faculty in accordance with the World Medical Association Declaration of Helsinki.

\section{Polymorphism Analysis}

The genomic DNA from blood samples were extracted using the white blood cells method formulated by Miller et al. [19]. After the isolation of DNA sample, hOGG1-Ser326Cys and APEAsp148Glu were amplified using polymerase chain reaction with suitable primers (Table 1). To detect the variations in these regions, restriction fragment length polymorphism analysis was performed using appropriate enzymes. The digested products were analyzed on $2 \%$ agarose gel stained with ethidium bromide and examined under transillumination.

\section{Statistical Analysis}

Statistical analyses were performed using the SPSS software version 11.5 (SPSS Inc., Chicago, IL, USA). Differences in the distribution of DNA repair genotypes or alleles between patient and control groups were tested using the $\chi^{2}$ test. Relative risk at $95 \%$ CIs was calculated as the OR.

\section{Results}

Demographic data and characteristics of the patient and control groups are shown in Table 2. There were no significant differences between the controls and patients in terms of age; however, sex, smoking habit, and alcohol consumption were statistically significantly different $(p<$ $0.05)$.

The distribution of hOGG1-Ser326Cys genotype and allele frequencies of OSCC in patients and controls are given in Table 3 . There were significantly more hOGG1Ser326Cys Cys allele carriers (Cys+) in the patient group than in the control group (Table 3). The results also 
Table 2. Demographic data and characteristics of the patient and control groups

\begin{tabular}{|c|c|c|c|}
\hline & $\begin{array}{l}\text { Control } \\
(n=160)\end{array}$ & $\begin{array}{l}\text { OSCC } \\
(n=132)\end{array}$ & $\begin{array}{l}p \\
\text { value }\end{array}$ \\
\hline Age, years & $57.73 \pm 13.20$ & $56.45 \pm 13.54$ & 0.425 \\
\hline Sex, female/male & $73 / 87$ & $48 / 84$ & 0.110 \\
\hline Smoking (no/yes), \% & $68.1 / 31.9$ & $37.9 / 62.1$ & 0.000 \\
\hline Alcohol (no/yes), \% & $96.9 / 3.1$ & $73.5 / 26.5$ & 0.000 \\
\hline \multicolumn{4}{|l|}{ Number of cigarettes/day, \% } \\
\hline$<20$ & & 50.6 & \\
\hline$>20$ & & 49.4 & \\
\hline \multicolumn{4}{|l|}{ Duration of smoking, $\%$} \\
\hline$<20$ years & & 28.4 & \\
\hline$>20$ years & & 71.6 & \\
\hline \multicolumn{4}{|l|}{ Duration of alcohol, $\%$} \\
\hline$<20$ years & & 38.1 & \\
\hline$>20$ years & & 61.9 & \\
\hline Oral care (no/yes), \% & & $59.1 / 40.9$ & \\
\hline Mechanical trauma (no/yes), $\%$ & & $59.8 / 40.2$ & \\
\hline \multicolumn{4}{|l|}{ Lymph node involvement } \\
\hline None & & 61.4 & \\
\hline$<3 \mathrm{~cm}$ & & 17.3 & \\
\hline $3-6 \mathrm{~cm}$ & & 21.3 & \\
\hline \multicolumn{4}{|l|}{ Tumor dimension, $\%$} \\
\hline$<4 \mathrm{~cm}$ & & 63.9 & \\
\hline$>4 \mathrm{~cm}$ & & 36.1 & \\
\hline \multicolumn{4}{|l|}{ Tumor localization } \\
\hline Tongue & & 47.2 & \\
\hline Lip & & 9.4 & \\
\hline Floor of mouth & & 14.2 & \\
\hline Gingival alveolar crest & & 15.0 & \\
\hline Retromolar trigon & & 6.3 & \\
\hline Hard palate & & 4.7 & \\
\hline Buccal mucosa & & 3.1 & \\
\hline \multicolumn{4}{|l|}{ Stage, $\%$} \\
\hline Early & & 42.5 & \\
\hline Advanced & & 57.5 & \\
\hline \multicolumn{4}{|l|}{ Stage } \\
\hline T1N0M0 & & 20.5 & \\
\hline T2N0M0 & & 21.3 & \\
\hline T3N0M0, T1-3N1M0 & & 22.0 & \\
\hline T4N0-1M0, T0-4N2M0, & & & \\
\hline T0-4N3M0, T0-4N0-3M1 & & 36.2 & \\
\hline \multicolumn{4}{|l|}{ Differentiation } \\
\hline Well & & 30.2 & \\
\hline Medium & & 28.7 & \\
\hline Poor & & 11.1 & \\
\hline Keratinization (no/yes), \% & & $28.6 / 71.4$ & \\
\hline
\end{tabular}

showed that carriers had a 2.8 -fold risk in the patient group ( $p<0.001 ; \chi^{2}=18.88$; OR 2.88; 95\% CI 1.77-4.68). Although in the control group, hOGG1-Ser326Cys Ser allele carriers (Ser+) were found statistically significant and had a 10-fold protective role against OSCC compared
Table 3. Distribution of hOGG1-Ser326Cys genotype and allele frequencies of patients and controls

\begin{tabular}{|c|c|c|c|c|c|}
\hline \multirow{2}{*}{$\begin{array}{l}\text { hOGG1- } \\
\text { Ser326Cys } \\
\text { rs1052133 }\end{array}$} & \multicolumn{2}{|c|}{$\begin{array}{l}\text { Control } \\
(n=160)\end{array}$} & \multicolumn{2}{|c|}{$\begin{array}{l}\text { Patient } \\
(n=132)\end{array}$} & \multirow[t]{2}{*}{$p$ value } \\
\hline & $n$ & $\%$ & $n$ & $\%$ & \\
\hline \multicolumn{6}{|l|}{ Genotypes } \\
\hline Ser/Ser & 114 & 71.3 & 61 & 46.2 & \\
\hline Cys/Cys & 2 & 1.3 & 14 & 10.6 & \\
\hline Ser/Cys & 44 & 27.5 & 57 & 43.2 & $\begin{array}{l}p=0.000 \\
\chi^{2}=24.26\end{array}$ \\
\hline \multicolumn{6}{|l|}{ Alleles } \\
\hline Ser & 272 & 85 & 179 & 67.80 & \\
\hline Cys & 48 & 15 & 85 & 32.19 & $\begin{array}{l}p=0.000 \\
\chi^{2}=24.32\end{array}$ \\
\hline
\end{tabular}

Table 4. Distribution of APE-Asp148Glu genotype and allele frequencies of patients and controls

\begin{tabular}{|c|c|c|c|c|c|}
\hline \multirow{2}{*}{$\begin{array}{l}\text { APE- } \\
\text { Asp148Glu } \\
\text { rs3136820 }\end{array}$} & \multicolumn{2}{|c|}{$\begin{array}{l}\text { Control } \\
(n=160)\end{array}$} & \multicolumn{2}{|c|}{$\begin{array}{l}\text { Patient } \\
(n=132)\end{array}$} & \multirow[t]{2}{*}{$p$ values } \\
\hline & $n$ & $\%$ & $n$ & $\%$ & \\
\hline \multicolumn{6}{|l|}{ Genotypes } \\
\hline Asp/Asp & 85 & 53.1 & 82 & 62.1 & \\
\hline Glu/Glu & 19 & 11.9 & 11 & 8.3 & \\
\hline Asp/Glu & 56 & 35.0 & 39 & 29.5 & $\begin{array}{l}p=0.277 \\
\chi^{2}=2.56\end{array}$ \\
\hline \multicolumn{6}{|l|}{ Alleles } \\
\hline Asp & 226 & 70.62 & 203 & 76.89 & \\
\hline Glu & 94 & 29.37 & 61 & 23.10 & $\begin{array}{l}p=0.08 \\
\chi^{2}=2.91\end{array}$ \\
\hline
\end{tabular}

to the patient group $\left(p<0.001 ; \chi^{2}=12.22\right.$; OR $0.10 ; 95 \%$ CI 0.02-0.47). hOGG1-Ser326Cys Ser/Ser $\left(p<0.001 ; \chi^{2}=\right.$ 18.82; OR 0.347; 95\% CI 0.214-0.563) and hOGG1Ser326Cys Cys/Cys $\left(p<0.001 ; \chi^{2}=12.25\right.$; OR 9.37; 95\% CI 2.09-42.03) genotype frequencies were significantly increased in the control group compared to the patient group. In addition, hOGG1-Ser326Cys, Ser/Cys carriers were higher in the patient group and had a 2 -fold risk for the development of the disease $\left(p=0.005 ; \chi^{2}=7.86\right.$; OR 2.00 95\% CI 1.22-3.26).

APE-Asp148Glu genotype frequencies are shown in Table 4. According to the statistical analysis, even though there were no statistically significant results, there were more APE-Asp148Glu Asp allele carriers (Asp+) among patients than in the controls $\left(p=0.32 ; \chi^{2}=0.98\right.$; OR 1.48; 
Table 5. Analysis of the disease stage, differentiation and tumor dimension according to hOGG1-Ser326Cys genotypes

\begin{tabular}{lll}
\hline & $\begin{array}{l}\text { Early stage } \\
\text { (grades 1-2), } \%\end{array}$ & $\begin{array}{l}\text { Advanced stage } \\
\text { (grades 3-4), \% }\end{array}$ \\
\hline Ser/Ser & 45.0 & 55.0 \\
Cys/Cys & 35.7 & 64.3 \\
Ser/Cys & 41.5 & 58.5 \\
\hline Differentiation & Poor & Well \\
\hline Ser/Ser & 8.9 & 91.1 \\
Cys/Cys & 9.1 & 90.9 \\
Ser/Cys & 15.0 & 85.0 \\
\hline Tumor dimension & $<4 \mathrm{~cm}$ & $>4 \mathrm{~cm}$ \\
\hline Ser/Ser & 66.7 & 33.3 \\
Cys/Cys & 72.7 & 27.3 \\
Ser/Cys & 58.5 & 41.5 \\
\hline
\end{tabular}

95\% CI 0.67-3.23) and APE-Asp148Glu Glu/Glu genotype carriers were found to be increased in the control group ( $p=0.321 ; \chi^{2}=0.98$; OR 0.67; 95\% CI 0.30-1.47).

Grades for disease, differentiation, and the level of tumor size were also investigated for hOGG1-Ser326Cys (Table 5) and APE-Asp148Glu (Table 6). Nevertheless, both genotype frequencies were not statistically important except that only hOGG1-Ser326Cys Ser allele carriers (Ser+) were found to be related statistically. Risk condition was seen with hOGG1-Ser326Cys Ser allele carriers $(S e r+)$ for the level of tumor size $(>4 \mathrm{~cm})$ as 1.5 -fold $(p=0.38$; OR 1.58; 95\% CI 0.39-6.39; Table 5).

\section{Discussion}

Given the prevalence and annual incidence of oral carcinoma, it is found that it affects more than 600,000 people each year and impacts primarily the quality of life including respiration process. It is well known that smoking habit alters and accounts for primary risk factors for not all cancer types but especially the oral cavity. According to the World Health Organization, this cancer can be prevented [20].

The main objective of our study is to determine the statistically important relation between hOGG1Ser326Cys and APE-Asp148Glu polymorphisms of DNA repair genes in oral squamous cell cancers (OSCC). In view of our results, especially hOGG1-Ser326Cys Cys, al-
Table 6. Analysis of disease stage, differentiation and tumor dimension according to APE-Asp148Glu genotypes

\begin{tabular}{lll}
\hline & $\begin{array}{l}\text { Early stage } \\
\text { (grades 1-2), \% }\end{array}$ & $\begin{array}{l}\text { Advanced stage } \\
\text { (grades 3-4), }\end{array}$ \\
\hline Asp/Asp & 35.0 & 65.0 \\
Glu/Glu & 63.6 & 36.4 \\
Asp/Glu & 52.8 & 47.2 \\
\hline Differentiation & Poor & Well \\
\hline Asp/Asp & 11.1 & 88.9 \\
Glu/Glu & 0 & 100 \\
Asp/Glu & 13.9 & 86.1 \\
\hline Tumor dimension & $<4 \mathrm{~cm}$ & $>4 \mathrm{~cm}$ \\
\hline Asp/Asp & 60.4 & 40.0 \\
Glu/Glu & 83.3 & 16.7 \\
Asp/Glu & 66.7 & 33.3 \\
\hline
\end{tabular}

lele carriers might have a facilitating role in OCD development. Our results showed the relation between oral cavity and DNA repair, especially hOGG1. For this reason, further studies with larger samples are needed to determine the disease mechanism in detail. To our knowledge, this is the first study focused on the potential contribution of APE1 and hOGG1 genotypes to OSCC pathogenesis with Turkish patients.

DNA damage might occur due to several endogenous and exogenous reasons including oxygen radicals. 8 -Hydroxy-2'-deoxyguanosine $(8-\mathrm{OH}-\mathrm{dG})$ is one of the prime factors for oxidative DNA damage [21]. Our body could compromise all the risk factors, which let the system away from homeostasis by several mechanisms such as DNA repair system. hOGG1 gene has the role of removing 8-OH-dG by coding the glycosylase/AP lyase to catalyze 8-OH-dG. Our study supported this finding by showing the correlation between Ser/Cys, Cys+ for the disease and Cys/Cys, Ser/Ser, Ser+ for protection. Our results need to support a large sample group and further analyze to make hOGG1 marker capability strong.

Not only is hOGG1 located and expressed in several tissues but also $8-\mathrm{OH}-\mathrm{dG}$ is found in almost all tobacco products. Hence, their role in oral cancer needs to be answered. Elahi et al. [22] suggested that aerodigestive tract tissues expressed hOGG1, which includes esophagus, larynx, tonsil, tongue, and mouth floor. They also showed that hOGG1 and orolaryngeal cancer risk are related in people who have smoking or drinking alcohol habits [22]. 
Xing et al. [23] studied squamous-cell carcinoma of the esophagus in the Chinese population and suggested that the 326Cys allele might have a role in the esophagus cancer mechanism. In addition, Tsai et al. [24] studied the relation between hOGG1 and oral cancer risk in a large Taiwanese population who were smokers. Their results pointed out that 326Cys allele carriers and smoking might have a positive relation [24].

DNA repair genes are still popular research area for cancer that never becomes old. There are a lot of studies on DNA repair and cancer. Farnebo et al. [25] investigated the role of XPC, XPD, XRCC1, and XRCC3 from DNA repair genes on head and neck cancer and showed association with the disease. Dos Santos Pereira et al. [26] also suggested, from a study on Brazilian population, that XRCC3-Met allele might have a role in OSCC mechanism.

We also need to determine the association between APE-Asp148Glu and OSCC. Even though we could not find statistically important relation, we found some susceptibility results that need to be clarified by large study groups such as Asp allele carriers being high in patients, $\mathrm{Glu} / \mathrm{Glu}$ genotype carriers increased in controls. Our study is the first of its kind, which focused on the relation between APE1 and oral cancer. There are limited research on APE1 and oral cancer. Souza and colleagues worked on $\mathrm{p} 53, \mathrm{APE} 1, \mathrm{hMSH} 2$, and ERCC1 proteins in lip squamous cell carcinoma using immunohistochemical methods and found the contribution of p53 and APE1. Not only did APE1 have a role in tumorigenesis, aging, angiogenesis, and oxidative stress signaling, but it also is an enzyme that works on BER mechanism to isolate the system from oxidative stress by apoptosis [25, 27-29]. If there is an obstacle or polymorphism on APE1 gene, the metabolism might end up in an uncontrolled cell division or escape from apoptosis. This result has helped clarify the association between oral cancer and APE1 by increasing the study population.

In conclusion, our results have pointed out especially hOGG1 Cys allele in patients by its potential risk for underlying mechanism of OSCC. Cys allele's role on DNA repair system is well known as Cys allele was revealed by decreasing the glycosylase/AP lyase enzyme activity, which might result in cancer by unrepaired DNA damage [30]. Combine this with our results about hOGG1 Cys, if $8-\mathrm{OH}-\mathrm{dG}$ has not catalyzed properly by hOGG1 and is stuck in the body, DNA repair system starts to work on a low capacity. In this case, polymorphisms that encode the related genes of hOGG1 might break down the DNA repair system capacity. Assembling 8-OH-dG in the system might be responsible for the development of OSCC. Also, further analyses on oral cavity anatomy and hOGG1 need to be carried out to solve their mechanism. Further trials with larger sample groups are warranted to unveil the possible involvement in the pathogenesis and biology of the oral cancer.

\section{Acknowledgements}

This work was supported by the Scientific Research Projects Coordination Unit of Istanbul University (project No. 42830). We would like to thank Mr. David Chapman for English editing.

\section{Disclosure Statement}

The authors declare no conflicts of interest.

\section{References}

1 Cummings CW, Flint PW, Harker LA, et al: Otolaryngology-Head and Neck Surgery, ed 4. Philadelphia, Mosby, Inc., 2005, vol 2, pp 1578-1617.

2 McDowell JD: An overview of epidemiology and common risk factors for oral squamous cell carcinoma. Otolaryngol Clin North Am 2006;39:277-294.

3 Tanis T, Cincin ZB, Gokcen-Rohlig B, Bireller ES, Ulusan M, Tanyel CR, Cakmakoglu B: The role of components of the extracellular matrix and inflammation on oral squamous cell carcinoma metastasis. Arch Oral Biol 2014;59:1155-1163.
4 Ries LAG, Melbert D, Krapcho M, et al: SEER Cancer Statistics Review 1975-2005. Bethesda, National Cancer Institute, 2008.

5 Barnes L, Eveson JW, Reichart P, Sidransky D: World Health Organization Classification of Tumours: Pathology and Genetics of Head and Neck Tumors. Lyon, IARC Press, 2005, pp 168-174.

6 Goode EL, Ulrich CM, Potter JD: Polymorphisms in DNA repair genes and associations with cancer risk. Cancer Epidemiol Biomarkers Prev 2002;11:1513-1530.
7 Kastan MB: DNA damage responses: mechanisms and roles in human disease: 2007 G.H.A. Clowes Memorial Award Lecture. Mol Cancer Res 2008;6:517-524.

8 Bao S, Wu Q, McLendon RE, et al: Glioma stem cells promote radioresistance by preferential activation of the DNA damage response. Nature 2006;444:756-760.

9 Helleday T, Petermann E, Lundin C, Hodgson B, Sharma RA: DNA repair pathways as targets for cancer therapy. Nat Rev Cancer 2008;8:193-204.

10 Martin SA, Lord CJ, Ashworth A: DNA repair deficiency as a therapeutic target in cancer. Curr Opin Genet Dev 2008;18:80-86.

hOGG1-Ser326Cys and OSCC 
11 Hoeijmakers JH: Genome maintenance mechanisms for preventing cancer. Nature 2001;411:366-374.

12 Zhang Y, Chen SY, Hsu T, Santella RM: Immunohistochemical detection of malondialdehyde-DNA adducts in human oral mucosa cells. Carcinogenesis 2002;23:207-211.

13 Santella RM, Gammon M, Terry M, et al: DNA adducts, DNA repair genotype/phenotype and cancer risk. Mutat Res 2005;592:2935.

14 Wood RD, Mitchell M, Sgouros J, Lindahl T: Human DNA repair genes. Science 2001;291: 1284-1289.

15 Attar R, Cacina C, Sozen S, Attar E, Agachan $B$ : DNA repair genes in endometriosis. Genet Mol Res 2010;9:629-636.

16 Ashton KA, Proietto A, Otton G, et al: Estrogen receptor polymorphisms and the risk of endometrial cancer. BJOG 2009;116:10531061.

17 Krupa R, Sobczuk A, Popławski T, Wozniak $\mathrm{K}$, Blasiak J: DNA damage and repair in endometrial cancer in correlation with the HOGG1 and RAD51 genes polymorphism. Mol Biol Rep 2011;38:1163-1170.
18 Aktuglu MB, Ayer M, Bireller ES, et al: Investigation of DNA repair gene variants on myelodysplastic syndromes in a Turkish population. Med Oncol 2014;31:174.

19 Miller SA, Dykes DD, Polesky HF: A simple salting out procedure for extracting DNA from human nucleated cells. Nucleic Acids Res 1988;16:1215.

20 WHO Global Oral Health Programme: The World Oral Health Report 2003. Geneva, WHO, 2003.

21 Kasai H: Analysis of a form of oxidative DNA damage, 8-hydroxy-2'-deoxyguanosine, as a marker of cellular oxidative stress during carcinogenesis. Mutat Res 1997;387:147-163.

22 Elahi A, Zheng Z, Park J, Eyring K, McCaffrey T, Lazarus P: The human OGG1 DNA repair enzyme and its association with orolaryngeal cancer risk. Carcinogenesis 2002;23:12291234.

23 Xing DY, Tan W, Song N, Lin DX: Ser326Cys polymorphism in hOGG1 gene and risk of esophageal cancer in a Chinese population. Int J Cancer 2001;95:140-143.

24 Tsai CW, Tsai MH, Tsou YA, et al: The joint effect of smoking and hOGG1 genotype on oral cancer in Taiwan. Anticancer Res 2012; 32:3799-3803.
25 Farnebo L, Stjernström A, Fredrikson M, et al: DNA repair genes XPC, XPD, XRCC1, and XRCC3 are associated with risk and survival of squamous cell carcinoma of the head and neck. DNA Repair (Amst) 2015;31:64-72.

26 Dos Santos Pereira J, Fontes FL, De Medeiros SR, De Almeida Freitas R, De Souza LB, Da Costa Miguel MC: Association of the XPD and XRCC3 gene polymorphisms with oral squamous cell carcinoma in a Northeastern Brazilian population: a pilot study. Arch Oral Biol 2015;64:19-23.

27 Vascotto C, Cesaratto L, Zeef LA, et al: Genome-wide analysis and proteomic studies reveal APE1/Ref-1 multifunctional role in mammalian cells. Proteomics 2009;9:10581074.

28 Shan JL, He HT, Li MX, et al: APE1 promotes antioxidant capacity by regulating $\mathrm{Nrf}-2$ function through a redox-dependent mechanism. Free Radic Biol Med 2015;78:11-22.

29 Li M, Wilson DM 3rd: Human apurinic/ apyrimidinic endonuclease 1 . Antioxid Redox Signal 2014;20:678-707.

30 Vogiatzi G, Tousoulis D, Stefanadis C: The role of oxidative stress in atherosclerosis. Hellenic J Cardiol 2009;50:402-409. 